\title{
Synergistic Effect of the Methanolic Extract of Lemongrass and Some Antibiotics to Treat Urinary Tract Bacteria
}

\author{
Samah Noor \\ Biology Department, Faculty of Sciences, King Abdel Aziz University, Saudi Arabia \\ Email: sonoor@kau.edu.sa
}

How to cite this paper: Noor, S. (2016) Synergistic Effect of the Methanolic Extract of Lemongrass and Some Antibiotics to Treat Urinary Tract Bacteria. Journal of Biosciences and Medicines, 4, 48-58. http://dx.doi.org/10.4236/jbm.2016.411006

Received: October 31, 2016

Accepted: November 27, 2016

Published: November 30, 2016

Copyright $\odot 2016$ by author and Scientific Research Publishing Inc. This work is licensed under the Creative Commons Attribution International License (CC BY 4.0).

http://creativecommons.org/licenses/by/4.0/

\begin{abstract}
Some medicinal plants are used traditionally in Saudi Arabia to treat many bacterial infections. Three plants, lemongrass (Oymbopogon citrates), lantana (Lantana camara), and wild olive leaves (Olea europaea) were collected, identified, extracted with either hot water or organic solvents (methanol, diethyl ether, ethyl acetate and n-butanol) to investigate their antibacterial activities against E. coli. The methanol extracts of lemongrass, lantana and olive showed the highest activities against Esherichia coil while aqueous extract exhibited the lowest activities. Thus, the antibacterial activities of the methanolic extract of the three tested plants were determined using agar well diffusion method against some bacterial pathogens, isolated from urine samples. The highest antibacterial activity was recorded for themethanolic extract of lemongrass against all tested bacteria, E. coli, $K$. pneumoniae, $P$. aeuroginosa, $P . m i-$ rabilis, $E$. faecalis and $S$. aureus. The tested bacteria differed with regard to their susceptibility to plant extracts. Lemongrass was the most active extract followed by lantana and wild olive extracts. Minimal inhibitory concentrations (MICs) of the methanolic extract of Lemongrass and some used antibiotics, Erythromycin, Tetracycline, Amoxicillin, Ciprofloxacin and Chloramphenicol were determined usingfluorescein diacetate method. Synergistic effect of the methanolic extract of lemongrass with the previous antibiotics against the tested clinical bacterial isolates was determined and the Fractional inhibitory concentrations (FIC) of different combination of the extract and the antibiotics were determined. FIC index (FICI) was calculated and it was ranged from $0.08-0.98$. The interaction between the tested plant extract and the tested antibiotics was either synergistic or additive effects and no antagonistic effect was recorded. In conclusion, methanolic extract of lemongrass singly or in combination with some antibiotics can be used to treat pathogenic bacteria that cause urinary tract infections.
\end{abstract}




\section{Keywords}

Antibacterial Activities, Fluorescein Diacetate, MIC, Methanol, Lemongrass, Antibiotics

\section{Introduction}

Klebsiella pneumoniae, Proteus, Pseudomonas aeruginosa and Escherichia coli are the most-frequent causative agents of acute urinary tract infections (UTI) that cause fatal infections if they are not treated properly or left untreated [1] [2] [3]. The urinary pathogens, E. coli found attached to the epithelium of the bladder and account to $75 \%$ 95\% of cases while other enterobacteria, Klebsiella, Proteus mirabilis, and Pseudomonas earuginosa and the Gram positive Staphylococcus saprophyticus isolates were less common. Enterococcus faecalis and Streptococcus agalactiae may be isolated from patients with complicated cystitis [4] [5]. Generally, all kinds of bacterial infections were treated with certain antibiotics but unfortunately and during recent years, bacteria are gradually becoming resistant due to the miss use of antibiotics. There is an accelerated search for novel antibacterial agents from plants which playing an important role in improving human health. For centuries in developed and undeveloped countries, plants or their extracts can be used as more effective and less toxic medical products or antibiotics to treat various infectious diseases [6]. Many plants produced many secondary products that can be used as antimicrobial agents which opened new avenues for novel natural antibiotics that can serve as substitutes for current antibiotics [7]. Many studied reported that plant extracts may have great action in treating multidrug resistant bacteria and fewer numbers of plant species have been studied for their secondary product productions while the rests of the plants still need studies [8] [9] [10]. Naik et al. (2010) [11] found that lemongrass strongly inhibited Gram positive bacteria compared to Gram negative bacteria while lantana exhibited antibacterial activity against Staphylococcus aureus, Escherichia coli, Bacillus subtilis and B. cereus due to the presence of forty-one components including caryophyllene, humulene, sabinene, bicyclogermacrene and davanone [12]. Themethanolic extract of wild olive showed the highest antibacterial activities compared to other organic solvents [13]. Phytochemical from plants can be used as antimicrobial agents [14], antiviral [15] and antioxidant [16]. They also stimulate enzyme activity [17] and immune system [18]. Plant extracts are rich in various components such as caffeine, tannins, amino acids, vitamins and saponins which are considered as hypocholesterolemic, neuroprotective, hypolipaemic, cardioprotective, anti infective, antimutagenic and antitumor activities as well as dental caries prevention [19]. The aim of this study was to evaluate the antibacterial activities of some plant extracts in vitro and the synergistic effect of the methanolic extract of lemongrass and some antibiotics to treat urinary tract bacteria was determined. 


\section{Material and Methods}

\subsection{Pathogenic Bacteria}

The tested bacteria were Escherichia coli, Pseudomonas aeruginosa, Klebsiella pneumonia, Proteus mirabilis, Enterococcus faecalis and Staphylococcus aureus. All bacterial isolates were obtained from mid stream urine specimens collected from patients at King Fahad General Hospital, Saudi Arabia and identified and processed according to standard guidelines [20].

\subsection{Medicinal Pant Materials}

Pants, lemongrass stalk and leaves (Cymbopogon citratus), lantana leaves (Lantana camara) and wild olive leaves (Olea europaea) were collected during May 2015, from various areas of $\mathrm{Al}$ Baha region, Saudi Arabia. Identification of the previous plants was carried out at the Department of Biology, KAU, SA.

\subsection{Preparation of Plant Extracts}

After cleaning the collected plants, they were dried and extracted with either hot water or organic solvents ( $50 \mathrm{~g} / 200 \mathrm{ml}$ of the solvent) for $24 \mathrm{~h}$. The organic solvents used were methanol, n-butanol, ethyl acetate or diethyl ether and the resultant extract was filtered using a glass wool and dried at $40^{\circ} \mathrm{C}$ to dryness under reduced pressure using rotary evaporator. The water extract was dried using lyophilizer and all the obtained extracts were dissolved in $1 \mathrm{ml} \mathrm{DMSO}$ and stored $-70^{\circ} \mathrm{C}$ until used [14].

\subsection{Antibacterial Activities of the Plant Extracts and Antibiotics}

Agar well diffusion assay was used to detect the antibacterial activities of the prepared extracts [21] and antibiotics. The antibiotics, Erythromycin, Tetracycline, Amoxicillin, Ciprofloxacin and Chloramphenicol (Sigma-Aldrich, St. Louis, Missouri, USA) were used.

Few microbial colonies were collected in sterile nutrient broth and adjusted to the turbidity of the standard of $0.5 \mathrm{McF}$ arland solutions [22] which has $4 \times 10^{6} \mathrm{CFU} / \mathrm{ml}$. Each Mueller Hinton agar (Oxoid) plate was inoculated with $1.0 \mathrm{ml}$ of the bacterial suspension. Agar wells were done using sterile cork borer $(0.6 \mathrm{~mm})$ and each well was filled with $100 \mu \mathrm{l}$ of the tested plant extract in DMSO. All inoculated plates were incubated at $37^{\circ} \mathrm{C}$ for $24 \mathrm{~h}$. Dimethyl sulfoxide (DMSO) was used as negative control and Ampicillin was used asa positive control. Mean diameter of inhibition zone of three replicated plates was determined. Minimal inhibitory concentrations (MICs) of plant extract, antibiotics or the mixture of both for all tested bacteria were determined in 96 well ELISA trays by the methods described by Chand et al. (1994) [23] and was modified by Aly and GumgumJee (2011) [9]. Each well contained $175 \mu \mathrm{l}$ of the bacterial suspension $\left(4 \times 10^{6} \mathrm{CFU} / \mathrm{ml}\right), 20 \mu \mathrm{l}$ the plant extract, or the solvent as control. After 40 minutes of incubation, fluorescein diacetate (FDA, $5 \mu \mathrm{l}$ of a $0.2 \% \mathrm{w} / \mathrm{v}$ in acetone) was added and the plates were incubated for 90 minutes. The obtained Green color from FDA hydrolysis was determined at $490 \mathrm{~nm}$ using an ELISA tray reader. 


\subsection{Fractional Inhibitory Concentration}

Fractional inhibitory concentration (FIC) is the lowest concentrations of the extract and the antibiotics in combination giving no detectable bacterial growth after incubation.FIC index values were calculated using the formula:

FIC index = MIC of extract in combination/MIC of extract alone + MIC of antibiotics in combination/MIC of antibiotics alone.

The combination defined synergy if $\sum F I C \leq 0.5$, additiveif $0.5<\sum F I C \leq 1$, indifference if $1<\Sigma$ FIC $\leq 4$ and antagonism as $\Sigma$ FIC $>4$ [24] [25] [26].

\subsection{Statistical Analysis}

Each experiment was carried out three times replicates and the means \pm standard deviation was recorded. Analysis of variance, ANOVA was used to determine the significant at $\mathrm{P} \leq 0.5$.

\section{Results}

Lemongrass (Oymbopogon citrates), lantana (Lantana camara), and wild olive (Olea europaea) were belonging to families Gramineae, Verbenaceae and Oleaceae, respectively (Table 1). The leaves of lantana and wild olive and shoot system of lemongrass were collected, identified, extracted with either hot water or organic solvents (methanol, diethyl ether, ethyl acetate and n-butanol) to investigate their antibacterial activities against E. coli. The methanolic extracts of lantana, lemongrass and wild olive showed the highest activities against $E$. coil with diameter of inhibition zones 28, 22 and $19 \mathrm{~mm}$, respectively while their aqueous extract exhibited the lowest activities, 7.7, 8.1 and $7.8 \mathrm{~mm}$ as shown in Table 2. Thus, the antibacterial activities of the methanolic extract of the three tested plants were determined against the tested bacteria, (Table 3)

Table 1. The studied medicinal plants to detect their antibacterial activities and the used parts.

\begin{tabular}{cccc}
\hline Common name & Scientific name & Family & Used part \\
\hline Lantana & Lantana camara & Verbenaceae & Leaves \\
Lemon grass & Oymbopogon citrates & Gramineae & Leaves \\
Wild olive & Olea europaea & Oleaceae & Leaves \\
\hline
\end{tabular}

Table 2. Antibacterial activities of the aqueous and organic extracts of three tested plant against E. coil as test organism.

\begin{tabular}{ccccccc}
\hline & \multicolumn{5}{c}{ Type of the extract } \\
\cline { 2 - 6 } Used plant & $\begin{array}{c}\text { Aqueous } \\
\text { extract (hot) }\end{array}$ & $\begin{array}{c}\text { Methanol } \\
\text { extract }\end{array}$ & Diethyl ether & Ethyl acetate & n-Butanol & F value \\
\hline Lantana & $7.7 \pm 1.0$ & $28 \pm 1.5$ & $12 \pm 0.6$ & $19 \pm 2.0$ & $15 \pm 1.4$ & $1.12^{*}$ \\
Lemon grass & $8.1 \pm 1.7$ & $22 \pm 2.0$ & $10 \pm 0.6$ & $17 \pm 2.6$ & $13 \pm 2.5 \mathrm{~b}$ & $32.4^{*}$ \\
Olive & $7.4 \pm 0.4$ & $19 \pm 2.0$ & $10 \pm 0.4$ & $18 \pm 2.5$ & $11 \pm 1.5$ & $3.46^{*}$ \\
\hline
\end{tabular}

*: significant results where the calculated $\mathrm{F}$ value $>\mathrm{F}$ Tabulated. 
Table 3. The antibacterial activities (diameter of the inhibition zone, $\mathrm{mm}$ ) of the methanolic extract of Lantana, lemongrass and olive against different pathogenic bacteria and compared to Ampicillin (positive control).

\begin{tabular}{ccccc}
\hline & \multicolumn{3}{c}{ Diameter o the inhibition zone $(\mathrm{mm})$} \\
\cline { 2 - 5 } Pathogenic bacteria & Lantana & Lemon-grass & Olive & $\begin{array}{c}\text { Ampicillin } \\
\text { (control, } 5 \mu \mathrm{g} / \mathrm{ml})\end{array}$ \\
\hline E. coli & $22 \pm 2.0$ & $28 \pm 1.5$ & $10 \pm 2.0$ & $30 \pm 2.5$ \\
K. pneumoniae & $20 \pm 2.1$ & $29 \pm 0.5$ & $14 \pm 1.5$ & $29 \pm 1.5$ \\
P. mirabilis & $20 \pm 2.2$ & $24 \pm 1.4$ & $10 \pm 0.4$ & $33 \pm 0.9$ \\
P. aeuroginosa & $20 \pm 1.0$ & $25 \pm 1.6$ & $8 \pm 0.5$ & $34 \pm 0.9$ \\
E. faecalis & $18 \pm 1.7$ & $20 \pm 1.4$ & $19 \pm 0.4$ & $26 \pm 0.5$ \\
S. aureus & $14 \pm 1.1$ & $20 \pm 1.0$ & $20 \pm 1.5$ & $27 \pm 1.0$ \\
Activity index & $19^{*}$ & 24.3 & $13.1^{*}$ & 29.8 \\
\hline
\end{tabular}

${ }^{+}$Activity index was calculated as the mean value of net zones of inhibition $(\mathrm{mm})$ against the pathogenic bacteria, * Significant difference compared to Ampicillin at $\mathrm{p} \leq 0.05$.

obtained from urine samples using agar well diffusion method. The tested bacteria were $K$. pneumoniae, $P$. aeuroginosa, $P$. mirabilis, E. faecalis and $S$. aureus. The highest antibacterial activity was recorded for the methanolic extract of lemongrass, followed by lantana and finally olive leave extract, against all tested bacteria, E. coli, K. pneumoniae, $P$. aeuroginosa, $P$. mirabilis, $E$. faecalis and $S$. aureus, with inhibition zone diameter ranged from $20-28 \mathrm{~mm}, 14-22 \mathrm{~mm}$ and $8-20 \mathrm{~mm}$. The tested bacteria differed with regard to their susceptibility to the plant extracts. Lemon grass methanolic extract was the most active extract for inhibition of the Gram negative E. coli and $K$. pneumonia followed by $P$. mirabilis and $P$. aeuroginosa. The effect of lantana leave extract was also on Gram negative bacteria especially $E$. coli and $K$. pneumoniae while olive leave extract inhibit mainly Gram positive bacteria, $S$. aureus and E. faecalis. Minimal inhibitory concentrations (MICs) of the methanolic extract of lemongrass and some used antibiotics, Erythromycin, Tetracycline, Amoxicillin, Ciprofloxacin and Chloramphenicol were determined using fluorescein diacetate method (Table 4). Synergistic effect of the methanolic extract of lemongrass with the previous antibiotics against the tested clinical bacterial isolates was determined (Table 5) and the Fractional inhibitory concentrations (FIC) of different combinations of lemongrass methanolic extract and some selected antibiotics were determined (Table 6). FIC index (FICI) was calculated and it was ranged from $0.08-0.98$. The interaction between plant extract and the tested antibiotics was either synergistic effect $\left(\sum \mathrm{FIC}\right.$ or FICI $\left.\leq 0.5\right)$ or additive effect $(0.5<\Sigma$ FIC $\leq$ $1)$ and no indifference $(1<\Sigma F I C \leq 4)$ or antagonistic $\left(\sum F I C>4\right)$. The interaction between the tested plant extract and the tested antibiotics was either synergistic or additive effects and no antagonistic effect was recorded. In conclusion, methanolic extract of lemongrass singly or in combination with some antibiotics can be used to treat urinary tract infections with different pathogenic bacteria. 
Table 4. Minimal inhibitory concentration (MIC) $\mu \mathrm{g} / \mathrm{ml}$ of methanolic extract of lemon grass and different antibiotics using Fluorescein diacetate method.

\begin{tabular}{|c|c|c|c|c|c|c|}
\hline \multirow{3}{*}{ Tested bacteria } & \multicolumn{6}{|c|}{ Minimal inhibitory concentration (MIC) } \\
\hline & \multirow{2}{*}{$\begin{array}{l}\text { Plant extract } \\
(\mathrm{mg} / \mathrm{ml})\end{array}$} & \multicolumn{5}{|c|}{ Antibiotic $(\mu \mathrm{g} / \mathrm{ml})$} \\
\hline & & Amx & Chl & Cip & Ery & Tet \\
\hline E. coli & $1.5 \pm 0.3$ & $3.7 \pm 0.6$ & $1.9 \pm 0.1$ & $0.07 \pm 0.0$ & $1.8 \pm 0.4$ & $1.96 \pm 0.1$ \\
\hline K. pneumoniae & $1.5 \pm 0.1$ & $0.9 \pm 0.4$ & $3.7 \pm 0.4$ & $0.07 \pm 0.0$ & $3.9 \pm 0.1$ & $1.96 \pm 0.1$ \\
\hline P. mirabilis & $2.2 \pm 0.5$ & $3.7 \pm 0.9$ & $0.9 \pm 0.0$ & $0.03 \pm 0.0$ & $1.9 \pm 0.3$ & $1.96 \pm 0.3$ \\
\hline P. aeuroginosa & $2.2 \pm 0.7$ & $7.5 \pm 0.6$ & $3.7 \pm 0.4$ & $0.03 \pm 0.0$ & $1.9 \pm 0.1$ & $3.96 \pm 0.4$ \\
\hline E. faecalis & $2.5 \pm 0.7$ & $15.6 \pm 0.1$ & $1.9 \pm 0.2$ & $0.03 \pm 0.0$ & $0.9 \pm 0.1$ & $3.96 \pm 0.5$ \\
\hline S. aureus & $2.7 \pm 0.7$ & $31.2 \pm 0.1$ & $1.9 \pm 0.0$ & $0.036 \pm 0.0$ & $3.9 \pm 0.2$ & $7.86 \pm 0.7$ \\
\hline
\end{tabular}

Ery: Erythromycin, Tet: Tetracycline, Amx: Amoxicillin, Cip: Ciprofloxacin, Chl: Chloramphenicol.

Table 5. Minimal inhibitory concentration (MIC) $\mu \mathrm{g} / \mathrm{ml}$ of the mixture of methanolic extract of lemon grass and different antibiotics using Fluorescein diacetate method.

\begin{tabular}{|c|c|c|c|c|c|}
\hline \multirow{2}{*}{ Tested bacteria } & \multicolumn{5}{|c|}{ Minimal inhibitory concentration (MIC) $\mu \mathrm{g} / \mathrm{ml}$} \\
\hline & $\mathrm{PE}+\mathrm{Amx}$ & $\mathrm{PE}+\mathrm{Chl}$ & $\mathrm{PE}+\mathrm{Cip}$ & PE + Ery & $\mathrm{PE}+$ Tet \\
\hline E. coli & $1.7 \pm 0.6$ & $0.9 \pm 0.1$ & $0.03 \pm 0.0$ & $1.4 \pm 0.2$ & $1.4 \pm 0.2$ \\
\hline K. pneumoniae & $0.5 \pm 0.4$ & $0.4 \pm 0.4$ & $0.05 \pm 0.0$ & $3.0 \pm 0.5$ & $1.7 \pm 0.2$ \\
\hline P. mirabilis & $1.7 \pm 0.9$ & $0.4 \pm 0.03$ & $0.02 \pm 0.0$ & $1.0 \pm 0.4$ & $1.5 \pm 0.2$ \\
\hline$P$. aeuroginosa & $3.5 \pm 0.1$ & $1.7 \pm 0.4$ & $0.02 \pm 0.0$ & $1.0 \pm 0.1$ & $3.5 \pm 0.5$ \\
\hline E. faecalis & $2.3 \pm 0.2$ & $0.9 \pm 0.2$ & $0.02 \pm 0.0$ & $0.5 \pm 0.0$ & $3.5 \pm 0.4$ \\
\hline S. aureus & $2.1 \pm 0.3$ & $0.9 \pm 0.04$ & $0.02 \pm 0.0$ & $0.9 \pm 0.2$ & $7.0 \pm 0.3$ \\
\hline
\end{tabular}

PF: Plant extract, Ery: Erythromycin, Tet: Tetracycline, Amx: Amoxicillin, Cip: Ciprofloxacin, Chl: Chloramphenicol

Table 6. Fractional inhibitory concentrations index of combination of the methanol extract of lemon grass and some antibiotics.

\begin{tabular}{ccccccccccc}
\hline \multirow{2}{*}{$\begin{array}{c}\text { Tested } \\
\text { bacteria }\end{array}$} & \multicolumn{2}{c}{ PE + Amx } & \multicolumn{2}{c}{ PE + Chl } & \multicolumn{2}{c}{ PE + Cip } & \multicolumn{2}{c}{ PE + Ery } & \multicolumn{2}{c}{ Tet + PE } \\
\cline { 2 - 10 } & FIC index & Eff. & FIC index & Eff. & FIC index & Eff. & FIC index & Eff. & FIC index & Eff. \\
\hline E. coli & 0.45 & S & 0.20 & S & 0.42 & S & 0.70 & A & 0.7 & A \\
K. pneumoniae & 0.55 & A & 0.46 & G & 0.71 & A & 0.08 & S & 0.9 & A \\
P. mirabilis & 0.45 & S & 0.10 & S & 0.66 & A & 0.52 & A & 0.78 & A \\
P. aeuroginosa & 0.46 & S & 0.20 & S & 0.66 & A & 0.52 & A & 0.89 & A \\
E. faecalis & 0.92 & A & 0.05 & S & 0.66 & A & 0.51 & A & 0.98 & A \\
S. aureus & 0.81 & A & 0.02 & S & 0.66 & A & 0.23 & S & 0.89 & A \\
\hline
\end{tabular}

S: synergistic effect, A: additive, Eff.: Effect, PF: Plant extract Ery: Erythromycin, Tet: Tetracycline, Amx: Amoxicillin, Cip: Ciprofloxacin, Chl: Chloramphenico. 


\section{Discussion}

The resistance of bacterial pathogensto ampicillin and trimethoprim sulfamethoxazole was increased and became major therapeutic problems. Multidrug-resistant bacteria isolates are widely distributed in the hospitals through patient contacts and are increasingly being isolated from community-acquired infections [2] [27] [28] [29]. In normal genitourinary tracts, the Gram-negative bacteria, Escherichia coli, Klebsiella pneumonia, Proteus mirabilis and occasionally Pseudomonas aeruginosa and the Gram-positive bacteria, Enterococcus faecalis, Staphylococcus aureus, S. saprophyticusis were recorded. In hospitalized patients, E. coli accounts for about 50\% of cases, Klebsiella, Proteus, Enterobacter, Pseudomonas and Serratia account for about $40 \%$ and the Gram-positive bacterial cocci account for the remainder [30]. Many studies were carried out to extract and characterize plant products that inhibit the most pathogenic bacteria which are difficult to be effectively treateddue to antibiotics limitation and availability [14] [31]. Inhibition of bacterial growth without harming the host cells represent the qualities required for safe and potent therapeutic agent. The plants lemongrass, lantana and wild olive were used traditionally in folkloric medicine in Saudi Arabia for their therapeutic activity in treating different pathogens and diseases [32] [33]. Lemongrass is a perennial aromatic medicinal grass mainly found in Najd, in the northern and eastern parts and commonly used as an infusion or tea for kidney remedy and fevers [32]. Aqueous and organic solvents of lemongrass, lantana and wild olive were compared. Methanol significantly extracts the active ingredient of the plants and was the most active in inhibition of E. coli growth. Similarly, the methanolic extract of Olae showed antibacterial activity similar to that of the antibiotic amoxicillin against $P$. aeruginosa [34]. In addition, the methanol extract of Spondias mombin showed excellent antibacterial activity with a mean zone of inhibition $\geq 11.1$ and activity index of 0.8 - 1.1 [35]. The antimicrobial effect of any extract depends on the used method for extraction, the used solvents and the used plant. The methanolic extract of lemongrass showed excellent antibacterial activities against all the tested bacteria with bacterial index of 24.3 and no significant difference was found when compared to Ampicillin (positive control). Lower activities were obvious in case of lantana extract and olive extract where the difference was significant at $\mathrm{p} \leq 0.05$ compared to Ampicillin. It was reported that the extract of lemongrass was effective against some bacteria including Acinetobacter baumanii, Aeromonas veronii, Enterococcus faecalis, Escherichia coli and Klebsiella pneumonia [36] [37]. The differences in the antibacterial effects of the three tested plant extracts may due to the qualities and quantities of active compounds in the extract. The extract of lemongrass was among the most significant active and nontoxic natural extracts due to free and bound flavonoid fractions and considered an important antimicrobial agent for many kinds of infections [11] [38]. The presence of the major volatile compounds nerol, geranial and geraniol in lemongrass extract was confirmed using Gas chromatography-mass spectrometry and all the tested pathogens are variably susceptible to these compounds [39]. The results of Al Yousef (2013) [40] showed that Lemongrass has a fungitoxic effect and cause a reduction in fungal viability and spore germination, loss of pigmentation 
and disrupted conidiospore structure, supporting a possible role of infection control and the use as antifungal agents. Promising antifungal activity of olive leaves against some plant pathogens was due to the presence of phenolic compounds [41]. Broth micro-dilution technique was used to determine theantiacterial activities and the same method was used for the antibiotic griseofulvin [42]. The calculated minimal inhibitory concentrations (MICs) for lemongrass were greater than that obtained for Erythromycin, Tetracycline, Amoxicillin, Ciprofloxacin and Chloramphenicol. FIC index (FICI) was ranged from $0.08-0.98$. The most prominent andsynergistic interaction was observed between lemongrass and Amoxicillin (Amx) against E. coli, P. mirabilis and $P$. aeuroginosa with $\Sigma$ FIC $\leq 0.5$. Ahmad A and Viljoen (2015) [39] calculated the MICs of lemongrass extract and $\mathrm{Ag}^{+}$for all the tested pathogens and they ranged from $0.032-1$ $\mathrm{mg} / \mathrm{ml}$ and $0.004-0.064 \mathrm{mg} / \mathrm{ml}$, respectively, while the MIC of their combination (FICI values) were ranged from $0.258-2.186$ which indicating synergy, additive and indifferent interactions. The combination of Ampicillin and fresh garlic extract showed synergistic interaction for different $S$. aureus isolates [43]. Further studies are needed for isolation, separation and identification of the active materials to be appliedas alternative drug for treatment of urinary system infections. The phenolics and polyphenols, essential oils; alkaloids; lectins and polypeptides are the most useful phytochemicals act as antimicrobial compounds. Their mechanisms of action vary according to their structure (Aly et al., 2013) [10] which may include enzyme inhibition, disruption of cell membranes, inactivation of the protein, complex formation with soluble proteins, DNA and bacterial cell walls [44] [45].

\section{Conclusion}

Very few studies confirm the viability of some plant extracts as antibiotics on urinary tract infections bacteria. In this study we supported the promising use of plant extract especially crude extracts of lemongrass, singly or in combination with some commonly used antibiotics. Similar combinations are usually used by the local people to treat bacterial infections associated with many diseases. Moreover, from our results, we suggest that lemon grass could be useful in the development of new antimicrobial drugs, especially against urinary tract infections caused by bacteria. In addition, more investigations are needed to identify potential medical uses of more traditional and herbal plants against different kinds of infections.

\section{References}

[1] Khan, A.U. and Musharraf, A. (2004) Plasmid-Mediated Multiple Antibiotic Resistance in Proteus mirabilis Isolated from Patients with Urinary Tract Infection. Medical Science Monitor. International Medical Journal of Experimental and Clinical Research, 10, 598-602.

[2] Maragakis, L.L. and Perl, T.M. (2008) Acinetobacter baumannir: Epidemiology, Antimicrobial Resistance, and Treatment Options. Clinical Infectious Diseases, 46, 1254-1263. https://doi.org/10.1086/529198

[3] Cunha, B.A. (2009) Antibiotic Essentials. 8th Edition, Jones \& Barlett, Sudbury, MA.

[4] Farrell, D.J., Morrissey, I., De Rubeis, D., Robbins, M. and Felmingham, D. (2003) A UK 
Multicentre Study of the Antimicrobial Susceptibility of Bacterial Pathogens Causing Urinary Tract Infection. Journal of Infection, 46, 94-100. https://doi.org/10.1053/jinf.2002.1091

[5] Mirsoleymani, S.R., Salimi, M., ShareghiBrojeni, M., Ranjbar, M. and Mehtarpoor, M. (2014) Bacterial Pathogens and Antimicrobial Resistance Patterns in Pediatric Urinary Tract Infections: A Four-Year Surveillance Study (2009-2012). International Journal of Pediatrics, 2014, 126-142.

[6] Betoni, J.E.C., Mantovani, R.P., Barbosa, L.N., Di Stasi, L.C. and Junior, A.F. (2006) Synergism between Plant Extract and Antimicrobial Drugs Used on Staphylococcus aureus Diseases. Memórias do Instituto Oswaldo Cruz, Rio de Janeiro, 101, 387-390.

[7] Donato, F., Maurin, D., Brun, P., Delahaye, T. and Salati, P. (2009) Constraints on WIMP Dark Matter from the High Energy PAMELA p/p Data. Physical Review Letters, 102, 071301. https://doi.org/10.1103/PhysRevLett.102.071301

[8] de Lemos, J.A., Blazing, M.A., Wiviott, S.D., Lewis, E.F., Fox, K.A., White, H.D., et al. (2004) Early Intensive vs a Delayed Conservative Simvastatin Strategy in Patients with Acute Coronary Syndromes: Phase $\mathrm{Z}$ of the A to Z Trial. Journal of the American Medical Association, 292, 1307-16. https://doi.org/10.1001/jama.292.11.1307

[9] Aly, M.M. and Gumgumjee, N.M. (2011) Antimicrobial Efficacy of Rheum palmatum, Curcuma longa and Alpinia officinarum Extracts against Some Pathogenic Microorganisms. African Journal of Biotechnology, 10, 12058-12063.

[10] Aly, M.M., Al-Ghamdi, M., Bafeel, S.O. and Khedr, A.M. (2013) Antimicrobial Activities and Phytochemical Analysis of the Essential Oil of Lavandula dentata and Plectranthus nudiflorus, Collected from Al Baha Region, Saudi Arabia. Life Science Journal, 10, 3302-3309.

[11] Naik, M.I., Fomda, B.A., Jaykumar, E. and Bhat, J.A. (2010) Antibacterial Activity of Lemongrass (Cymbopogon citratus) Oil against Some Selected Pathogenic Bacterias. Asian Pacific Journal of Tropical Medicine, 3, 535-538. https://doi.org/10.1016/S1995-7645(10)60129-0

[12] Saikia, A.K. and Sahoo, R.K. (2011) Chemical Composition and Antibacterial Activity of Essential oil of Lantana camara L. Middle-East Journal of Scientific Research, 8, 599-602

[13] Paudel, S., Magrati, T. and Lamichhane, J.R. (2011) Antimicrobial Activity of Wild Olive Crude Extracts in Vitro. International Journal of Pharma Sciences and Research, 2, 110-113.

[14] El Sayed, H.A. and Aly, M.M. (2014) Antibacterial Activities of Six Medicinal Plants Used Traditionally by Saudi People to Treat Common Diseases. British Biotechnology Journal, 4, 499-510. https://doi.org/10.9734/BBJ/2014/8532

[15] Garcia, S.M.A. (2003) Review of the Ecosystem Approach to Fisheries. In: Ba, M., Chavance, P., Gascuel, D., Pauly, D. and Vakily, M., Eds., Pêcheries Maritimes, Écosystèmes et SociétésenAfrique de POuest. Un Demi-siècle de Changement, Actes du Symposium International de Dakar (Sénégal), ACP-UE.

[16] Elsawi, N., Backer, W., Aly, M.M. and Baz, L. (2010) Assessment of Therapeutic Value of Black Costus (Saussurea lappa) Using Several Parameters. Journal of International Environmental Application \& Science, 5, 832-841.

[17] Platel, K. and Srinivasan, K. (1996) Influence of Dietary Spices or Their Active Principles on Digestive Enzymes of Small Intestinal Mucosa in Rats. International Journal of Food Sciences and Nutrition, 47, 55-59. https://doi.org/10.3109/09637489609028561

[18] Middleton, E. and Kandaswam, C.C. (1992) Effects of Flavonoids on Immune and Inflammatory Cell Functions. Biochemical Pharmacology, 43, 1167-1179. https://doi.org/10.1016/0006-2952(92)90489-6 
[19] Weber, J.M., Ruzindana-Umunyana, A., Imbeault, L. and Sircar, S. (2003) Inhibition of Adenovirus Infection and Adenain by Green Tea Catechins. Antiviral Research, 58, $167-$ 173. https://doi.org/10.1016/S0166-3542(02)00212-7

[20] Clinical and Laboratory Standard Institute (CLSI) (2012) Administrative Procedures M100S18. CLSI, Wayne.

[21] Holder, I.A. and Boyce, S.T. (1994) Agar Well Diffusion Assay Testing of Bacterial Susceptibility to Various Antimicrobials in Concentrations Non-Toxic for Human Cells in Culture. Burns, 20, 426-429. https://doi.org/10.1016/0305-4179(94)90035-3

[22] McFarland, J. (1907) The Nephelometer: An Instrument for Estimating the Number of Bacteria in Suspensions Used for Calculating the Opsonic Index and for Vaccines. Journal of the American Medical Association, 49, 1176-1178. https://doi.org/10.1001/jama.1907.25320140022001f

[23] Chand, S., Lusunzi, I., Veal, D.A.L., Williams, R. and Karuso, P. (1994) Rapid Screening of the Antimicrobial Activity of Extracts and Natural Products. Journal of Antibiotics, 47, 1295-1304. https://doi.org/10.7164/antibiotics.47.1295

[24] Eliopoulos, G.M. and Eliopoulos, C.T. (1988) Antibiotic Combinations: Should They Be Tested? Clinical Microbiology Reviews, 1, 139-156. https://doi.org/10.1128/CMR.1.2.139

[25] Isenberg, H.D. (1992) Synergism Testing: Broth Microdilution Checkerboard and Broth Macrodilution Methods. In: Isenberg, H.D., Ed., Clinical Microbiology Procedures Handbook, 2th Edition, American Society Microbiology, Washington DC, 1-28.

[26] Petersen, P.J., Labthavikul, P., Jones, C.H. and Bradford, P.A. (2006) In Vitro Antibacterial Activities of Tigecycline in Combination with Other Antimicrobial Agents Determined by Chequerboard and Time-Kill Kinetic Analysis. Journal of Antimicrobial Chemotherapy, 57, 573-576. https://doi.org/10.1093/jac/dki477

[27] Helmi, N.R., Zaman, R.M. and Aly, M.M. (2013) Prevalence of Gram-Positive Bacteria in Jeddah, Kingdom of Saudi Arabia: Study of Antimicrobial Resistance Patterns and Molecular Typing. International Journal of Pharma and Bio Sciences, 4, 1231-1245.

[28] Halwani, M.A., Tashkandy, N.A.J., Aly, M.M., Al Masoudi, S. and Dhafar, O.O. (2015) Incidence of Antibiotic Resistance Bacteria in Jeddah's Ministry of Health Hospitals, Saudi Arabia. Advances in Microbiology, 5, 780-786. https://doi.org/10.4236/aim.2015.512082

[29] Zaman, R.M., Aly, M.M. and Helmi, N.R. (2015) Antimicrobial Susceptibility Pattern of Gram-Negative Bacilli Isolated from a Teaching Hospital in Jeddah, Saudi Arabia. African Journal of Microbiology Research, 9, 2145-2158. https://doi.org/10.5897/AJMR2015.7584

[30] Imam, T.H. (2013) Introduction to Urinary Tract Infections. www.msdmanuals.com/professional/genitourinary-disorders

[31] Aly, M.M. and Bafiel, S. (2008) Screening for Antimicrobial Activity of Some Medicinal Plants in Saudi Arabia. World Conference on Medical and Aromatic, Cape Town, 9-14 November 2008.

[32] Lebling, R.W. (1999) Handbook of Arabian Medicinal. www.geocities.com/Athens/Troy/4040/HERBALME.htm(9of15)

[33] Al Garni, E.H. and Hafez, D.A. (2015) Effect of Extracts of Some Herbs on Fertility of Male Diabetic Rats. Journal of American Science, 11, 165-175.

[34] Mariita, R.M., Orodho, J.A., Okemo, P.O., Kirimuhuzya, C., Otieno, J.N. and Magadula, J.J. (2011) Methanolic Extracts of Aloe secundiflora Engl. inhibits in Vitro Growth of Tuberculosis and Diarrhea-Causing Bacteria. Pharmacognosy Research, 3, 95-99. https://doi.org/10.4103/0974-8490.81956 
[35] Adegoke, A.A., Aiyegoro, O.A. and Stenstrom, T.A. (2016) Effect of Interaction of Methanol Leaf Extract of Spondias mombin (Linn) and Amoxicillin on Some Diarrheagenic Escherichia coli. Tropical Journal of Pharmaceutical Research, 15, 475-480.

https://doi.org/10.4314/tjpr.v15i3.7

[36] Tiziana Baratta, M., Damien Dorman, H.J., Deans, S.G., Cristina Figueiredo, A. and Barroso, J.G. (1998) Antimicrobial and Antioxidant Properties of Some Commercial Essential Oils. Flavour and Fragrance Journal, 13, 235-244. https://doi.org/10.1002/(SICI)1099-1026(1998070)13:4<235::AID-FFJ733>3.0.CO;2-T

[37] Cimanga, K., Tona, L., Apers, S., Bruyne, T., Hermans, N., Totte, J., et al. (2002) Correlation between Chemical Composition and Antibacterial Activity of Essential Oils of Some Aromatic Medicinal Plants Growing in the Democratic Republic of Congo. Journal of Ethnopharmacology, 79, 213-220. https://doi.org/10.1016/S0378-8741(01)00384-1

[38] Dupuis, G., Johri, B., Bandoni, R.J. and Towers, G.H. (1972) Cinnamylphenols as Inhibitors of Fungal Growth. Canadian Journal of Microbiology, 18, 929-932. https://doi.org/10.1139/m72-142

[39] Ahmad, A. and Viljoen, A. (2015) The in Vitro Antimicrobial Activity of Cymbopogon Essential Oil (Lemon Grass) and Its Interaction with Silver Ions. Phytomedicine, 22, 657-665. https://doi.org/10.1016/j.phymed.2015.04.002

[40] Al Yousef, S.A. (2013) Antifungal Activity of Volatiles from Lemongrass (Cymbopogon citratus) and Peppermint (Mentha piperita) Oils against Some Respiratory Pathogenic Species of Aspergillus. International Journal of Current Microbiology and Applied Sciences, 2, 261-272.

[41] Winkelhousen, E., Pospiech, R. and Laufenberg, G. (2005) Antifungal Activity of Phenolic Compounds Extracted from Dried Olive Pomace. Bulletin of the Chemists and Technologists of Macedonia, 24, 41-46.

[42] Araujo, C.R., Miranda, K.C. Fernandes, O.F.L., Soares, A.J. and Silva, M.R.R (2009) In Vitro Susceptibility Testing of Dermatophytes Isolated in Goiania, Brazil, against Five Antifungal Agents by Broth Microdilution Method. Rev. Inst. Med. trop. S. Paulo, 51, 9-12.

[43] Pillai, R., Trivedi, N.A. and Bhatt, J.D. (2013) Studies on in Vitro Interaction of Ampicillin and Fresh Garlic Extract against Staphylococcus aureus by Checkerboard Method. Ancient Science of Life, 33, 114-118.

[44] Ali, A.A. (1999) Studies on Some Medicinal Plants as a Source of Antifungal Substances in North Africa. MSc Thesis, Institution of African Research and Studies, Cairo University, Cairo.

[45] Cowan, M.M. (1999) Plant Products as Antimicrobial Agents. Clinical Microbiology Reviews, 12, 564-582. 
Submit or recommend next manuscript to SCIRP and we will provide best service for you:

Accepting pre-submission inquiries through Email, Facebook, LinkedIn, Twitter, etc. A wide selection of journals (inclusive of 9 subjects, more than 200 journals)

Providing 24-hour high-quality service

User-friendly online submission system

Fair and swift peer-review system

Efficient typesetting and proofreading procedure

Display of the result of downloads and visits, as well as the number of cited articles

Maximum dissemination of your research work

Submit your manuscript at: http://papersubmission.scirp.org/

Or contact jbm@scirp.org 